\title{
Effect of attractant stimuli, starvation period and food availability on digestive enzymes in the redclaw crayfish Cherax quadricarinatus (Parastacidae)
}

\author{
Hernán J. Sacristán ${ }^{1,2}$, Héctor Nolasco-Soria ${ }^{3}$, Laura S. López Greco ${ }^{1,2, *}$ \\ ${ }^{1}$ Biology of Reproduction and Growth in Crustaceans, Department of Biodiversity and Experimental Biology, FCE y N, \\ University of Buenos Aires, Cdad. Univ. C1428EGA, Buenos Aires, Argentina \\ ${ }^{2}$ Instituto de Biodiversidad y Biologia Experimental y Aplicada (IBBEA), CONICET-UBA, Argentina \\ ${ }^{3}$ Centro de Investigaciones Biológicas del Noroeste, S. C. La Paz, Baja California Sur 23090, México
}

\begin{abstract}
Chemical stimuli in crayfish have been extensively studied, especially in the context of social interactions, but also to a lesser extent in relation to food recognition and the physiological response of digestive enzymes. This is particularly important in commercial species in order to optimize the food supplied. The first objective of this study was to determine whether incorporation of squid meal (SM) in food (base feed, BF) acts as an additional attractant for Cherax quadricarinatus and, if so, the concentration required for optimal effectiveness. Incorporation of SM was evaluated through individual and group behavioral tests. The second objective was to analyze the effect of food availability on behavior and level of digestive enzyme activity after short-term (48 h) and long-term (16 d) starvation periods. To assess the effect of either starvation period, 3 different treatments were conducted: no feed (control), available BF, and BF present but not available. Individual and group behavior showed no differences among treatments with different percentages of SM inclusion in BF. The time spent in chambers with different percentages of SM was similar in all treatments. Levels of amylase activity and soluble protein, as a function of food availability after a short- or long-term starvation period, were not altered. Digestive enzyme activity was not affected after $2 \mathrm{~d}$ of starvation in response to the treatment. However, change was observed in enzymatic profiles after juveniles were deprived of food for $16 \mathrm{~d}$. The main responses were given by lipase, protease and trypsin activity. Based on previous studies and the present results, we propose a hypothesis for a possible regulation of the digestive and intracellular lipase activities depending on food availability.
\end{abstract}

KEY WORDS: Chemical stimuli $\cdot$ Crustaceans $\cdot$ Digestive enzyme $\cdot$ Food searching behavior $\cdot$ Food attractants $\cdot$ Starvation

\section{INTRODUCTION}

Redclaw crayfish Cherax quadricarinatus is a freshwater decapod crustacean, native to northern Queensland (Australia) and southeast Papua New Guinea. This species possesses many desirable biological characteristics for successful aquaculture, such as ease of reproduction, tolerance of crowding,

${ }^{*}$ Corresponding author: laura@bg.fcen.uba.ar relatively rapid growth rate and flexible eating habits (Gillespie 1990, Merrick \& Lambert 1991, Gu et al. 1994). In natural ecosystems, crayfish have polytrophic feeding habits and have been described as predators, omnivores and/or detritivores, consuming a variety of macrophytes, benthic invertebrates, algae and detritus (Saoud et al. 2013). The flexible feeding habits of crayfish suggest that they might re-

(C) The authors 2014. Open Access under Creative Commons by Attribution Licence. Use, distribution and reproduction are unrestricted. Authors and original publication must be credited. 
spond to a very broad spectrum of chemicals (Tierney \& Atema 1988). Indeed, aquatic organisms use chemical signals as sources of information for a number of ecological decisions such as food localization (Moore \& Grills 1999), mate searching (Ameyaw-Akumfi \& Hazlett 1975, Tierney \& Dunham 1982, Dunham \& Oh 1992), predator detection (Hazlett 1989), shelter choice (Tamburri et al. 1996) and advertisement of social status (Karavanich \& Atema 1998, Zulandt Schneider et al. 1999, Kozlowski et al. 2003).

Crustaceans exhibit relatively slow and intermittent feeding activity and this has an impact on food acquisition and processing. These behavioral characteristics affect the physical properties of feed pellets, such as water stability (hydrostability), and as a consequence, water quality (Saoud et al. 2012). Inasmuch as food is a significant expense in aquaculture production systems, the need to maximize food consumption and reduce wasted food is fundamental for economic success (Lee \& Meyers 1996).

Considering the importance of chemical signals during the development of crustaceans, it might be assumed that the incorporation of attractants to food would allow individuals to find potential food in a shorter period of time, increasing the possibility of ingestion (Mendoza et al. 1997). It has been demonstrated that squid meal acts as a stimulant, increasing food consumption in Homarus gammarus (Mackie \& Shelton 1972), Penaeus stylirostris and P. setiferus (Fenucci et al. 1980), P. monodon (Smith et al. 2005), and Litopenaeus vannamei (Nunes et al. 2006). Similarly, shrimp protein hydrolysates stimulate feed consumption in C. quadricarinatus (Arredondo-Figueroa et al. 2013). There are few studies regarding the use of chemoattractant substances incorporated into the diets of cultured freshwater decapod crustaceans (Arredondo-Figueroa et al. 2013) and their effect on feeding responses (Tierney \& Atema 1988, Lee \& Meyers 1996, Kreider \& Watts 1998).

Under natural conditions where crayfish may feed ad libitum on foods appearing in various forms and compositions, differences in digestive processes are likely to occur (Kurmaly et al. 1990). Crustaceans alternate between periods of feeding and non-feeding during their development as a result of sequential molting (Vega-Villasante et al. 1999). Molting involves several stages with different feeding behaviors, including the cessation of external food intake from late premolt through early postmolt; therefore, energy needs can be met with different available external food sources or lipid reserves. Digestive enzymes are used as a physiological response to fasting (Cuzon et al. 1980, Jones \& Obst 2000, Muhlia-
Almazán \& García-Carreño 2002, Rivera-Pérez \& García-Carreño 2011, Calvo et al. 2013). Artificiallyinduced fasting and starvation may allow elucidation of the metabolic routes used in hierarchical order during molting and may initiate alternative biochemical and physiological adaptation mechanisms (Barclay et al. 1983, Comoglio et al. 2008). The midgut gland of crustaceans is the main organ for synthesis and secretion of digestive enzymes (including proteinase, lipase and carbohydrase), absorption and storage of nutrients (lipids and glycogen), which can be mobilized during the non-feeding periods (Icely \& Nott 1992, Ong \& Johnston 2006). The level of the digestive enzymes in decapod crustaceans does not remain constant during the molt cycles (van Wormhoudt 1974) as a result of both internal and external factors such as starvation and the availability, quantity and quality of food. In C. quadricarinatus, LoyaJavellana et al. (1995) demonstrated that crayfish are potentially capable of regulating their digestive processes according to food availability.

In the present study, we focused on factors affecting feeding in C. quadricarinatus. Our main hypothesis was that chemical signals from food affect digestive enzyme activity, and this response is modulated by food availability and starvation periods. Our first objective was to determine whether squid additives make food more attractive to crayfish and, if so, what concentration of additives elicits maximum food searching behavior. The second objective was to analyze the effect of food availability on digestive enzyme activity after short- and long-term starvation periods. This information may be useful to understand food searching behavior, and to determine the modulating effect of food presence on digestive physiology in order to design new diets and maximize food handling for the species.

\section{MATERIALS AND METHODS}

\section{Live specimens}

Juvenile redclaw crayfish were hatched from a reproductive female stock supplied by Centro Nacional de Desarrollo Acuícola (CENADAC), Corrientes, Argentina $\left(27^{\circ} 22^{\prime} 42.09^{\prime \prime} \mathrm{S}, 58^{\circ} 40^{\prime} 52.41^{\prime \prime} \mathrm{W}\right)$. Each ovigerous female (mean wet body weight \pm $\mathrm{SD}=59.8 \pm 3.2 \mathrm{~g}$ ) with 100 to 150 eggs was maintained in an individual glass aquarium (length $x$ width $\times$ height $=60 \times 40 \times 30 \mathrm{~cm}$ ) containing $30 \mathrm{l}$ of dechlorinated tap water, under continuous aeration $\left(5 \mathrm{mg} \mathrm{O} \mathrm{O}_{2}\right.$ $\mathrm{l}^{-1}$ ). The temperature was maintained at $27 \pm 1^{\circ} \mathrm{C}$ by 
Altman water heaters $\left(100 \mathrm{~W}\right.$, precision $\left.1^{\circ} \mathrm{C}\right)$, and the photoperiod was $14 \mathrm{~h}$ light:10 h dark cycle. Each aquarium was provided with a PVC tube $(10 \mathrm{~cm}$ diameter, $25 \mathrm{~cm}$ long) as a shelter (Jones 1995). Females were fed daily ad libitum with Elodea sp. and commercial TetraColor granules $\left(\right.$ TETRA $^{\circledR}$, min. crude protein $47.5 \%$, min. crude fat $6.5 \%$, max. crude fiber $2.0 \%$, max. moisture $6.0 \%$, min. phosphorus $1.5 \%$, and min. ascorbic acid $100 \mathrm{mg} \mathrm{kg}^{-1}$ ) according to Bugnot \& López Greco (2009) and Sánchez De Bock \& López Greco (2010). At stage 3, juveniles became independent (Levi et al. 1999) and were separated from 6 mothers, then pooled and maintained under the same conditions mentioned above (based on previous studies; Vazquez et al. 2008, Stumpf et al. 2010, Tropea et al. 2010, Calvo et al. 2013) until they reached the desired weight.

For all experiments, we used a base food (BF, Table 1), specially formulated for C. quadricarinatus by Gutiérrez \& Rodríguez (2010). Crude protein, total lipids, ash, and moisture contents of diets were determined at National Institute for Fisheries Research and Development (INIDEP), Mar del Plata, Argentina according to AOAC (1990); the proximal composition of the BF was $37.98 \pm 0.94 \%$ crude protein, $6.05 \pm$ $0.08 \%$ lipid, $16.05 \pm 0.11 \%$ ash and $4.03 \pm 0.03 \%$ moisture.

\section{Effect of squid attractant on juvenile ability to detect food}

For the behavioral experiment, a $30 \times 40 \times 20 \mathrm{~cm}$ glass aquarium without water flow was designed (Fig. 1A) based on Jaime-Ceballos et al. (2007). The
Table 1. Formulation of the reference diet for Cherax quadricarinatus prepared as in Gutiérrez \& Rodríguez (2010). Mineral premix (mg kg$\left.{ }^{-1}\right): \mathrm{ZnSO}_{4}, 50 ; \mathrm{MgSO}_{4}, 35$; $\mathrm{MnSO}_{4}, 15 ; \mathrm{CoSO}_{4}, 2.5 ; \mathrm{CuSO}_{4}, 3 ; \mathrm{KI}$, 3. Vitamin premix (mg $\mathrm{kg}^{-1}$, unless otherwise noted): A (retinol), $3000 \mathrm{UI} \mathrm{kg}^{-1}$; D, $600 \mathrm{UI} \mathrm{kg}{ }^{-1}$; E (alpha tocopheryl acetate), 60; K, 5; C (ascorbic acid), 150; B1 (thiamin), 10; B (riboflavin), 10; Vitamin B6 (piridoxin), 7; B12, 0.02; biotin, 0.4; pantothenic acid, 35; folic acid, 6; niacin, 80; choline, 500; inositol, 100

\begin{tabular}{|lc|}
\hline Ingredients & Percentage \\
\hline Fish meal & 28 \\
Soybean meal & 39 \\
Pre-jellified starch & 19 \\
Soybean oil & 6 \\
Bentonite & 6 \\
Mineral premix & 1 \\
Vitamin premix & 1 \\
\hline
\end{tabular}

aquarium was divided into 3 similarly-sized, parallel chambers: the middle chamber was used for acclimation, and the right and left compartments were used as 'attractant chambers'. The aquarium was placed inside a white box to minimize disturbance to crayfish behavior. Food containers $(4.5 \times 4.5 \times 6 \mathrm{~cm}$, Fig. 1B) consisted of an acrylic box surrounded by nylon mesh (1 $\mathrm{mm}$ mesh pore). There was a net tube $(1.5 \times 4.5 \mathrm{~cm}$, diam. $\times$ length) inside the container to prevent small particles of food from falling out when the acrylic structure was moved by the animals.

The ingredient tested as a food attractant was squid meal (SM, Illex argentinus), and its inclusion in $\mathrm{BF}$ was analyzed. The protein concentrate extraction of SM was performed by the Soxhlet method, with isopropyl alcohol as a solvent. The protein residue was then oven-dried at $80^{\circ} \mathrm{C}$ for $24 \mathrm{~h}$ according to
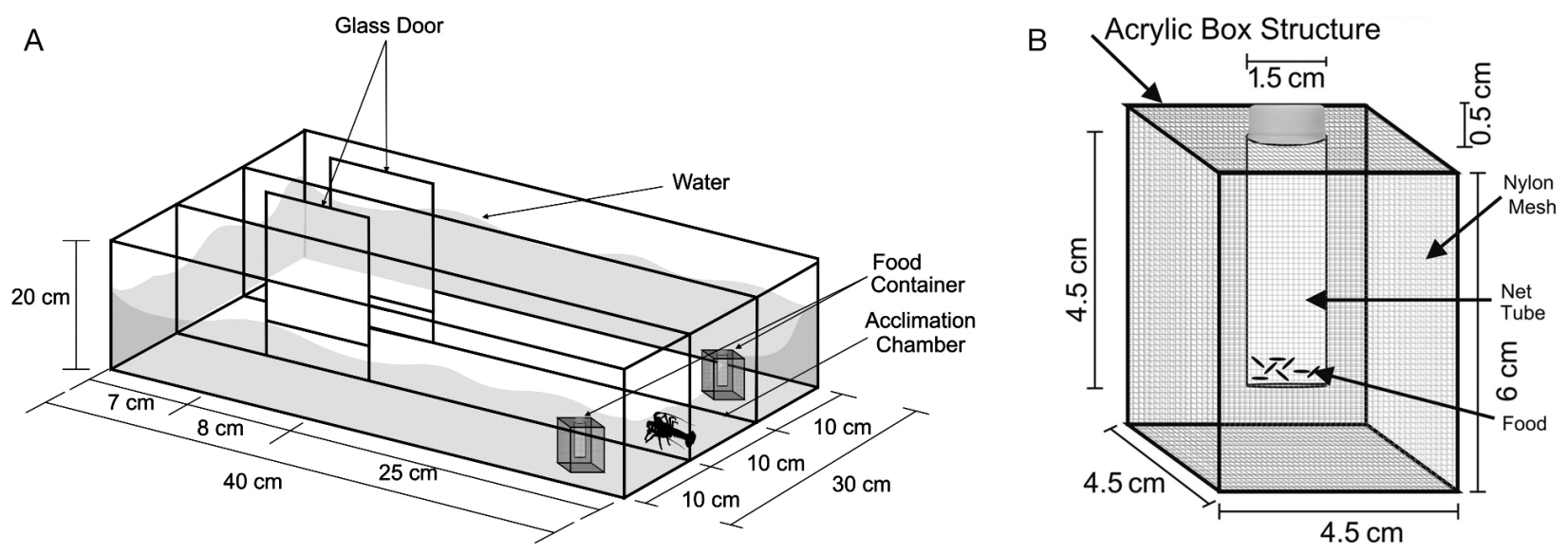

Fig. 1. Aquarium and container design for tests of food attraction with the redclaw crayfish Cherax quadricarinatus. (A) glass aquarium device showing the position of the glass doors, acclimation chamber, water level and food container positions;

(B) food container device 
Díaz et al. (1999). The SM integration in BF was performed according to Díaz et al. (1999) and the chemoattractant concentrations in the BF of the different treatments were: 0 (control), 0.25, 1, 2.5 and $10 \%(\mathrm{w} / \mathrm{w})$; TetraColor granules were used as a reference positive control. The paired comparisons (Treatments) were: (1) $0 \%$ (feed control): no food versus $\mathrm{BF}_{\text {; }}(2) 0.25 \%$ : $\mathrm{BF}+0.25 \% \mathrm{SM}$ versus $\mathrm{BF}_{;}(3) 1 \%$ : $\mathrm{BF}+1 \% \mathrm{SM}$ versus $\mathrm{BF} ;$ (4) $2.5 \%$ : $\mathrm{BF}+2.5 \% \mathrm{SM}$ versus $B F$; (5) $10 \%$ : $B F+10 \%$ SM versus $B F$; and (6) reference positive control: TetraColor granules versus no food.

The ability to detect food was evaluated under 2 experimental conditions: individually (April 2012) and in groups (April 2013). Twenty individual juvenile behaviors were observed in the glass aquarium per treatment, except for the reference positive control ( $\mathrm{N}=10$ ) (weight: $1.35-3.25 \mathrm{~g} ; \mathrm{N}=110$ ) and group behavior was observed with 4 juveniles (weight: 1.21 to $3.75 \mathrm{~g}$ ) per experiment with 5 replicates for each treatment $(\mathrm{N}=60)$. The group behavior experiment was only performed for Treatments (1), (3) and (5) due to the results of individual behavior experiments.

Test specimens were acclimated to BF for $1 \mathrm{wk}$ prior to the assays, and behavioral experiments were always performed between 09:00 and 13:00 $\mathrm{h}$ in the presence of artificial light, in order to avoid any effects of circadian rhythms (Sacristán et al. 2013). All crayfish were starved for $48 \mathrm{~h}$ prior to behavioral evaluation, and all were at intermolt, since it has been suggested that the level of responsiveness varies from stage to stage of the molt cycle (Harpaz et al. 1987). Only test specimens with complete sensory appendages (i.e. antennae and antennules) were selected.

At the beginning of each assay, juveniles were maintained in the acclimation chamber for 10 min as in Nunes et al. (2006). After each trial, water was discarded completely, the aquarium was washed with tap water and refilled with new filtered water. Water quality parameters were measured in order to avoid water quality effects on responses by test specimens to the chemoattractant (Lee \& Meyers 1996). These parameters, i.e. dissolved oxygen $(6 \pm 1 \mathrm{mg}$ $\left.\mathrm{l}^{-1}\right), \mathrm{pH}(7.7 \pm 0.5)$, hardness $\left(80 \pm 10 \mathrm{mg} \mathrm{l}^{-1}\right.$ as $\mathrm{CaCO}_{3}$ equivalents), and temperature $\left(27 \pm 1^{\circ} \mathrm{C}\right)$ were within the ranges recommended for aquaculture (Jones 1997, Boyd \& Tucker 1998).

Behavioral response to the presence of the attractant was recorded visually by 1 observer positioned in front of the glass aquarium. The location of SM (i.e. left or right chamber) was chosen randomly for each behavior session. After acclimation, the glass doors of the chamber were opened and the following variables were evaluated: (1) first choice (SM or no SM) of the juveniles, and (2) residence time in each chamber for 10 min (a period established in a preliminary bioassay). The food amount (BF, SM+BF or TetraColor) offered in each trial was $5 \%$ of the mean body weight of all crayfish. The percentage of positive choice was calculated as: positive choice $(\%)=($ total number of positive choices / total number of comparisons) $\times 100$, as in Nunes et al. (2006). The \% residence time was calculated as: residence time $(\%)=($ total time of positive residence / total assay time) $\times 100$.

\section{Effect of food availability on digestive enzyme activity}

To evaluate the effect of food availability on digestive enzymes, 2 experiments were performed according to length of starvation period (short or long). In both experiments, treatments were: (1) no BF (control), (2) available BF (ABF), (3) BF present but not available (NABF). For each treatment, an $18 \times 35 \times$ $19 \mathrm{~cm}$ plastic aquarium was used; food was unprotected in the ABF treatment but was protected by a food container in the NABF treatment. Either the food or the food container was placed in the middle of the aquarium. In the ABF and NABF treatments, the amount of food offered was $5 \%$ of the juvenile's weight.

\section{Expt 1: short-term starvation period}

For this experiment, 144 intermolt phase crayfish were selected (weight: $1.14-3.99 \mathrm{~g}$ ). Juveniles were starved in a common aquarium $(53 \times 40 \times 12 \mathrm{~cm})$ at a constant temperature $\left(27 \pm 1^{\circ} \mathrm{C}\right)$ for $48 \mathrm{~h}$. Each treatment consisted of 4 replicates $(\mathrm{N}=48)$. Before the beginning of the experiment, 12 starved crayfish were randomly placed and acclimated for $1 \mathrm{~h}$ in each aquarium. For each treatment (control, ABF and NABF), 8 crayfish were anesthetized in cold water after $0,5,10,30,60$ and $120 \mathrm{~min}$, and the midgut gland was dissected.

\section{Expt 2: long-term starvation period}

A total of 72 intermolt phase crayfish (weight: $1.75-5.17 \mathrm{~g}$ ) were selected and starved for $16 \mathrm{~d}$ in individual plastic containers $\left(500 \mathrm{~cm}^{3}\right)$ filled with $350 \mathrm{ml}$ of dechlorinated water under continuous aeration. These containers were placed in $53 \times 40 \times$ 
$12 \mathrm{~cm}$ aquaria with water maintained at $27 \pm 1^{\circ} \mathrm{C}$. Starvation days were established in preliminary studies. During this period, the plastic containers were cleaned and water was renewed 3 times a week (during experiments no molting organisms were observed). Thereafter, the same procedure as in Expt 1 was performed, but the analysis times were 0, 30 and $120 \mathrm{~min}$; at each time 8 crayfish were anesthetized in cold water and the midgut gland was dissected.

Enzymatic preparation and activity assays

At the end of short- and long-term starvation experiments, the midgut glands were dissected, weighed $( \pm 0.1 \mathrm{mg})$ and immediately frozen at $-80^{\circ} \mathrm{C}$. Each midgut gland was homogenized in Tris- $\mathrm{HCl}$ buffer (50 mM, pH 7.5, 1:4 w/v) in an ice-water bath, with a Potter homogenizer. After centrifugation at $10000 \times g$ for $30 \mathrm{~min}$ at $4^{\circ} \mathrm{C}$ (Fernández Gimenez et al. 2009), the lipid layer fraction was removed and the supernatant was stored at $-80^{\circ} \mathrm{C}$ until used as an enzyme extract for the enzymatic analysis. The absorbance of enzymatic assays was read on a JASCO CRT-400 spectrophotometer.

The amount of total soluble protein was evaluated with the Coomassie blue dye method according to Bradford (1976) using serum bovine albumin as the standard. Total proteinase activity was assayed using $1 \%$ azocasein as the substrate in $50 \mathrm{mM}$ Tris- $\mathrm{HCl}$, pH 7.5 (García-Carreño 1992). One proteinase unit was defined as the amount of enzyme required to increase 0.01 optical density (OD) units $\mathrm{min}^{-1}$ at $440 \mathrm{~nm}$ (López-López et al. 2005). Lipase activity of each enzyme extract was determined according to Versaw et al. (1989). The assay mixture consisted of $100 \mu \mathrm{l}$ of sodium taurocholate $100 \mathrm{mM}, 1900 \mu \mathrm{l}$ of buffer Tris-HCl (50 mM, pH 7.5) and $20 \mu \mathrm{l}$ of enzyme extract. After pre-incubation $\left(25^{\circ} \mathrm{C}\right.$ for $\left.5 \mathrm{~min}\right), 20 \mu \mathrm{l}$ of $\beta$-naphthyl caprylate substrate (Goldbio N-100) $200 \mathrm{mM}$ in dimethyl sulfoxide (DMSO) was added. The mixture was incubated at $25^{\circ} \mathrm{C}$ for $30 \mathrm{~min}$. Then $20 \mu$ Fast Blue BB (100 mM in DMSO) was added. The reaction was stopped with $200 \mu$ l of trichloroacetic acid (TCA, $0.72 \mathrm{~N}$ ), and clarified with $2.76 \mathrm{ml}$ of ethyl acetate:ethanol (1:1 v/v). Absorbance was recorded at $540 \mathrm{~nm}$. One lipase unit was defined as the amount of enzyme required to increase 0.01 OD units $\min ^{-1}$ at $540 \mathrm{~nm}$ (López-López et al. 2005).

Amylase activity of each extract was determined according to Vega-Villasante et al. (1993). The assay mixture consisted of $500 \mu \mathrm{l}$ Tris- $\mathrm{HCl}$ (50 mM, pH 7.5) and $5 \mu$ l enzyme extract; $500 \mu$ starch solution $(1 \%$ in Tris- $\mathrm{HCl}, 50 \mathrm{mM}, \mathrm{pH}$ 7.5) was added to start the reaction. The mixture was incubated at room temperature for $10 \mathrm{~min}$. Amylase activity was determined by measuring the production of reducing sugars resulting from starch hydrolysis as follows: immediately after incubation, $200 \mu$ l of sodium carbonate $(2 \mathrm{~N})$ and $1.5 \mathrm{ml}$ DNS reagent were added to the reaction mixture and the mixture was boiled for $15 \mathrm{~min}$ in a water bath. The volume was adjusted to $10 \mathrm{ml}$ with distilled water, and the colored solution was read at $550 \mathrm{~nm}$. Reference tubes were prepared similarly, but crude extract was added after the DNS reagent. One amylase unit was defined as the amount of enzyme required to cause an increase of 0.01 OD units $\mathrm{min}^{-1}$ at $550 \mathrm{~nm}$ (López-López et al. 2005).

Trypsin activity was assayed according to Erlanger et al. (1961). The substrate solution was prepared using $100 \mathrm{mM}$ benzoyl Arg-p-nitroanilide (BAPNA) dissolved in $1 \mathrm{ml}$ of DMSO and brought to a volume of $100 \mathrm{ml}$ with Tris-HCI $50 \mathrm{mM}$, pH 8.2 containing $10 \mathrm{mM} \mathrm{CaCl}_{2}$. Activity was measured by mixing $80 \mu \mathrm{l}$ enzyme extract and $1.25 \mathrm{ml}$ of substrate solution, and then the mixture was incubated for $20 \mathrm{~min}$ at $37^{\circ} \mathrm{C}$. Subsequently, $0.25 \mathrm{ml}$ of acetic acid was added, and the hydrolysis of BAPNA was determined by measurement of free p-nitroaniline at $410 \mathrm{~nm}$. The trypsin activity was measured at 0,30 , and $120 \mathrm{~min}$ for Expts 1 and 2.

\section{Statistical analysis}

The positive choice and residence time data derived from paired comparisons of feeding behaviors were tested using the chi-squared test of independence (Zar 1999) and 1-way ANOVA (Sokal \& Rohlf 1995) respectively. Digestive enzyme data from the short- and long-term starvation experiments were analyzed using generalized linear mixed models (GLMMs) with the statistical program $\mathrm{R}$ and the GLMMs package (Zuur et al. 2009), including treatments (control, $\mathrm{ABF}$ and $\mathrm{NABF}$ ) and time as fixed factors. The significance level was set at $\alpha=0.05$.

\section{RESULTS}

\section{Effect of chemoattractant on juvenile response}

The results of individual and group crayfish behaviors are shown in Table 2. For individual crayfish response, no significant differences were found among 
Table 2. Number of comparisons, positive choices and residence times of juvenile Cherax quadricarinatus individual and group behavior. BF: base food, SM: squid meal. Treatments: $0 \%$ (control): no food versus BF; $0.25 \%$ : $\mathrm{BF}+0.25 \% \mathrm{SM}$ versus $\mathrm{BF} ; 1 \%: \mathrm{BF}+1 \% \mathrm{SM}$ versus $\mathrm{BF} ; 2.5 \%: \mathrm{BF}+2.5 \% \mathrm{SM}$ versus $\mathrm{BF} ; 10 \%: \mathrm{BF}+10 \% \mathrm{SM}$ versus $\mathrm{BF}^{2}$ positive control: $\mathrm{TETRA}^{\circledR}$ TetraColor granules versus no food

\begin{tabular}{|c|c|c|c|c|c|c|}
\hline \multirow{2}{*}{$\begin{array}{l}\text { Treatment } \\
\text { ( } \% \text { of } \mathrm{SM} \text { in } \mathrm{BF})\end{array}$} & \multicolumn{3}{|c|}{ Individual behavior } & \multirow[b]{2}{*}{$\begin{array}{c}\text { No. of } \\
\text { comparisons }\end{array}$} & \multirow{2}{*}{$\begin{array}{c}\text { Group behavior } \\
\text { Positive } \\
\text { choices (\%) }\end{array}$} & \multirow[b]{2}{*}{$\begin{array}{c}\text { Residence } \\
\text { time (\%) }\end{array}$} \\
\hline & $\begin{array}{c}\text { No. of } \\
\text { comparisons }\end{array}$ & $\begin{array}{c}\text { Positive } \\
\text { choices (\%) }\end{array}$ & $\begin{array}{c}\text { Residence } \\
\text { time (\%) }\end{array}$ & & & \\
\hline 0 & 20 & 55 & $41.28 \pm 4.18$ & 5 & 50 & $38.02 \pm 10.96$ \\
\hline 0.25 & 20 & 50 & $52.94 \pm 4.24$ & - & - & - \\
\hline 1 & 20 & 40 & $47.99 \pm 6.33$ & 5 & 40 & $40.23 \pm 5.35$ \\
\hline 2.5 & 20 & 50 & $42.36 \pm 3.62$ & - & - & - \\
\hline 10 & 20 & 40 & $38.90 \pm 5.61$ & 5 & 70 & $37.70 \pm 3.30$ \\
\hline Positive control & 10 & 20 & $34.36 \pm 8.39$ & - & - & - \\
\hline
\end{tabular}

treatments with different percentages of SM included in the BF. Residence times in the chambers with different percentages of SM were similar in all treatments $(p=0.22)$. Group behavior showed that the percentage of positive choice was the same for all treatments $(p>0.05)$. Additionally, the crayfish did not preferentially stay in the chamber with the attractant $(\mathrm{p}=0.91)$.

\section{Expt 1: short-term starvation period}

The results of specific enzyme activity for amylase, lipase, protease, trypsin and soluble protein level in the short-term starvation experiment are presented in Fig. 2. The digestive enzyme profiles and soluble protein from midgut gland extracts showed a similar pattern among treatments. Specifically, crayfish from the NABF treatment had significantly lower levels ( $p<0.05$ ) of amylase activity at 5 and $120 \mathrm{~min}(5.24$ and $5.14 \mathrm{U} \mathrm{mg}$ protein ${ }^{-1}$ respectively) than the control and ABF (Fig. 2A). No significant difference was found between ABF and the control group ( $p>0.05)$. Lipase activity of crayfish was not significantly affected $(p=0.19)$ by the treatments over the $120 \mathrm{~min}$ period of the experiment (Fig. 2B). Protease activity in the midgut gland of the juveniles in the NABF treatment was significantly lower (1.02 U mg protein $^{-1}$ ) than those in the control and ABF treatments at $5 \mathrm{~min}(\mathrm{p}<0.05)$ (Fig. 2C). Moreover, the crayfish in the ABF group differed significantly from the control ( $\mathrm{p}<0.05$ ) only at $30 \mathrm{~min}$.

Trypsin activity showed significant differences $(\mathrm{p}<$ 0.05) among control, ABF and NABF at $120 \mathrm{~min}$ (Fig. 2D); furthermore, the soluble protein level of the crayfish was not significantly affected $(p=0.47)$ by the treatments over 120 min (Fig. 2E).

\section{Expt 2: long-term starvation period}

The effect of food availability on the digestive enzyme activity of crayfish after long-term starvation is shown in Fig. 3. There was no significant difference in amylase activity $(\mathrm{p}=0.37)$ among treatments over the 120 min observation period (Fig. 3A). Lipase activity of $\mathrm{ABF}$ exhibited a significantly lower activity ( $\mathrm{p}<$ 0.05 ) than NABF at 30 and 120 min (61.52 and $48.31 \mathrm{U}$ mg protein ${ }^{-1}$ respectively) (Fig. 3B). There were significant differences in protease activity $(p<0.05)$ among $\mathrm{NABF}$, control and $\mathrm{ABF}$ at the initial time (Fig. 3C). At $30 \mathrm{~min}$, the protease activity in NABF (1.15 U mg protein ${ }^{-1} \mathrm{~min}^{-1}$ ) and ABF (1.18 U mg protein $^{-1}$ ) was significantly $(p<0.05)$ lower than the control group. The ABF decreased significantly $(\mathrm{p}<0.05)$ to $0.70 \mathrm{U} \mathrm{mg} \mathrm{protein}^{-1}$ at $120 \mathrm{~min}$. Trypsin activity for ABF showed significant differences $(p<0.05)$ compared to the control and NABF treatments at the end of the experiment (Fig. 3D), but the levels of soluble protein concentration in the crayfish starved for $16 \mathrm{~d}$ did not show significant differences $(p=0.13)$ among treatments during the time assayed (Fig. 3E). Similar results were found when total enzyme activity (U mg midgut gland ${ }^{-1}$ ) was calculated (data not shown).

\section{DISCUSSION}

Although crayfish have polytrophic feeding habits (Saoud \& Ghanawi 2013), this study showed that squid protein extract in the tested concentration range did not increase the attractiveness of feed to Cherax quadricarinatus. This result disagrees with other studies on Pleoticus muelleri, Homarus gammarus, Litopenaeus vannamei, Penaeus monodon, $P$. setiferus and P. stylirostris (Mackie \& Shelton 1972, 

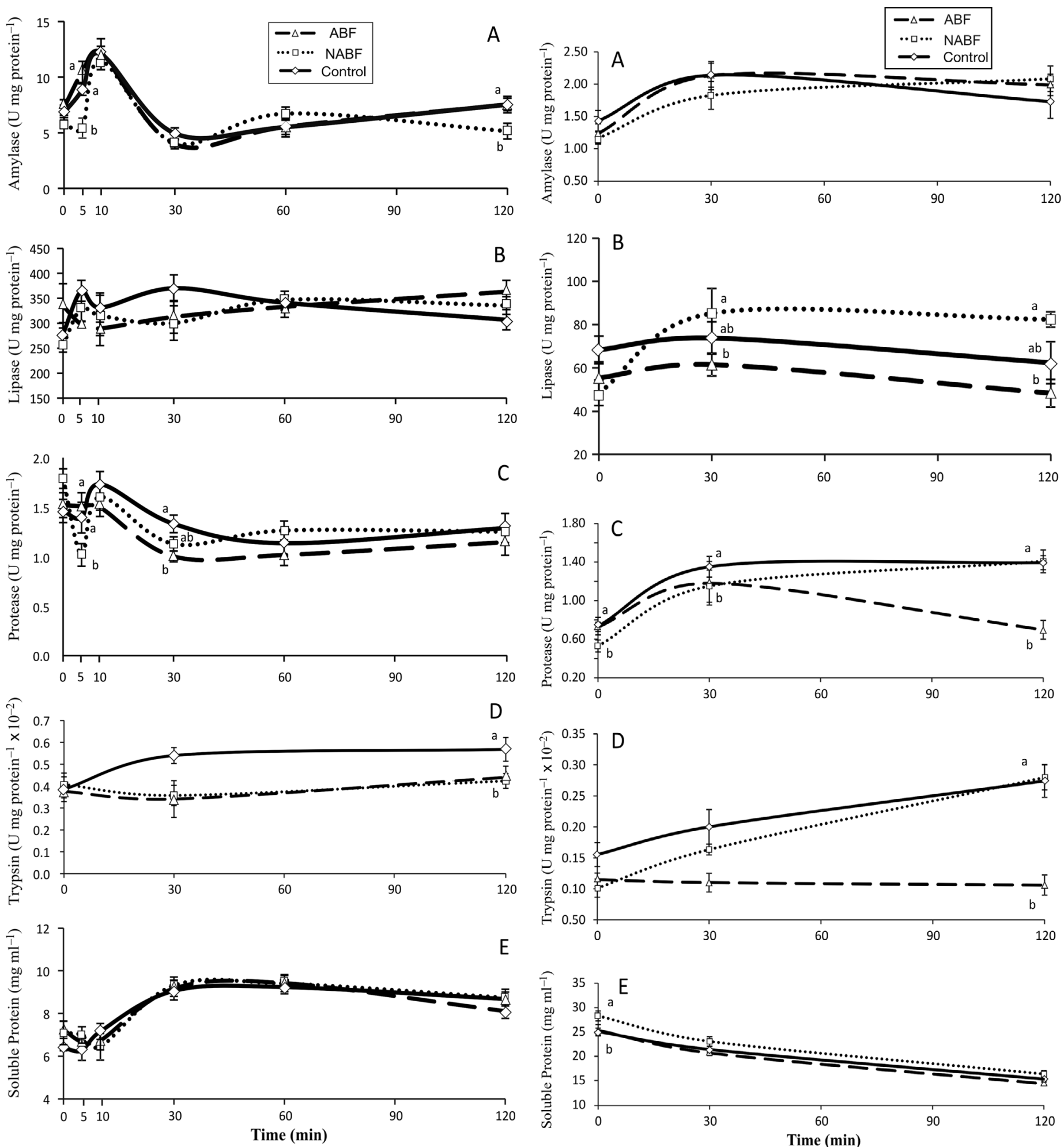

Fig. 2. Specific enzyme activities in the midgut gland of Cherax quadricarinatus juveniles after the short-term (48 h) starvation experiment. (A) Amylase, (B) lipase, (C) protease, (D) trypsin, (E) soluble protein. Values are shown as mean \pm SE. Different letters indicate significant differences $(\mathrm{p}<$ 0.05). ABF: available base food; NABF: no available base food; control: no base food

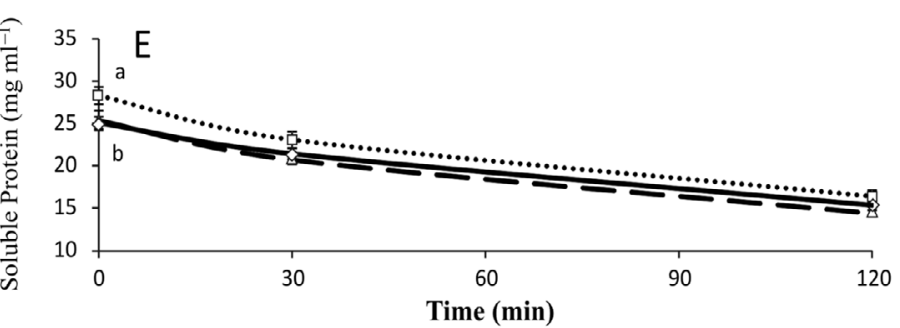

Fig. 3. Specific enzyme activities in the midgut gland of Cherax quadricarinatus juveniles after the long-term (16 d) starvation experiment. (A) Amylase, (B) lipase, (C) protease, (D) trypsin, (E) soluble protein. Values are shown as mean \pm SE. Different letters indicate significant differences $(\mathrm{p}<$ 0.05). ABF: available base food; NABF: no available base food; control: no base food 
Fenucci et al. 1980, Díaz et al. 1999, Smith et al. 2005, Nunes et al. 2006) even though the SM and the method for incorporating it into the experimental feed were the same across all studies. However, these other studies were performed on marine crustaceans (lobsters and shrimp), whereas this study is the first to test the effectiveness of SM as an attractant for a freshwater decapod.

The experiment on food detection shows that crayfish wander around the aquarium regardless of where food is localized. Subsequently, when the animal is sufficiently close to or in contact with potential food, their chemoreceptors play a fundamental role in acceptance or rejection of potential food (Heinen 1980). Thus, given the feeding habits of C. quadricarinatus and our results, we propose the hypothesis that C. quadricarinatus mainly finds food due to the time they invest in environmental wandering. Given that our food searching behavior experiments were carried out in stagnant water, and that odor plumes are strongly affected by flow dynamics for detection of chemical signals (Weissburg 2011), crayfish food detection should also be studied using flowing water. Additionally, food searching behavior could be analyzed in a Y-maze apparatus to enhance the sensitivity of the experimental setup. Mackie (1973) determined that the squid-soluble extract is rich in proline, glycine, alanine and arginine. According to Heinen (1980), glycine and arginine act as attractants in decapod crustaceans. Tierney \& Atema (1988) found that cellobiose and sucrose are important feeding stimulants for Orconectes rusticus; the amino acids glycine and glutamate elicited feeding movements in O. rusticus and $O$. virilis crayfish. Amino acids are abundant in the tissues of marine organisms and they probably guide predators and scavengers to food. Amino acids may likewise signal food availability to crayfish (Tierney \& Atema 1988). Further research is needed to determine if the use of complex ingredients such as krill meal, or simple components like amino acids can act as signals for food detection in C. quadricarinatus.

Under natural conditions where crayfish may feed ad libitum on food of various forms and compositions, differences in digestive processes are likely to occur (Kurmaly et al. 1990). In the study on foregut evacuation, return of appetite and gastric fluid in $C$. quadricarinatus, Loya-Javellana et al. (1995) demonstrated that ingested food was evacuated linearly with time in crayfish fed daily, and in a somewhat curvilinear trend in those fed every $2 \mathrm{~d}$. This would indicate that crayfish are potentially capable of regulating their digestive processes according to food availability (Loya-Javellana et al. 1995).
Our results on starvation period and food availability demonstrated that crayfish starved for $48 \mathrm{~h}$ had a higher digestive enzyme specific activity than crayfish starved for $16 \mathrm{~d}$. Relative to the highest activity level of amylase, lipase, protease and trypsin recorded during the analysis period of both starvation treatments, we found 4.95, 3.70, 0.29 and 1.12 times, respectively, more activity in crayfish starved in the short-term experiment compared to crayfish starved for the long-term. However, in terms of total activity, the differences were smaller, with similar total protease and trypsin activity, and only $60 \%$ higher lipase and amylase activity. Therefore, we can conclude that digestive enzyme activity is not affected after $2 \mathrm{~d}$ of starvation and in response to treatment. However, different enzymatic profiles were observed in C. quadricarinatus juveniles deprived of food for $16 \mathrm{~d}$. The main responses occurred in lipase, protease and trypsin activity, which were higher in control and NABF groups; however, this may have been due to the protein provided by the food (in the case of specific activity), or due to the additional weight provided by the ingested food to the tissue (midgut gland), in the case of total activity; in both cases decreasing the enzyme activity.

The levels of amylase activity and soluble protein as a function of food availability after short- or longterm starvation were not altered. Calvo et al. (2013), analyzing C. quadricarinatus juveniles (1 g), observed that starvation did not have an effect on amylase activity, but an accentuated tendency to decrease after $50 \mathrm{~d}$ of starvation and to increase after $40 \mathrm{~d}$ of re-feeding. Our results are opposed to those of Clifford \& Brick (1983), who found that fasting Macrobrachium rosenbergii use the energy from the oxidation of carbohydrates.

Our research demonstrates that C. quadricarinatus juveniles respond differently to food availability after a long-term starvation period (16 d). These results agree with Calvo et al. (2013), who observed low levels of lipase activity after a 50 d starvation period, suggesting that lipase is not synthesized when food is not available. In the same species, Yudkovski et al. (2007) demonstrated that lipase transcripts decrease in the hepatopancreas during non-feeding stages. Studying the effect of starvation on the expression of lipase transcripts in Litopenaeus vannamei, RiveraPérez \& García-Carreño (2011) showed that 2 types of lipase exist: a digestive lipase and an intracellular lipase (lysosomal). The digestive lipase is only found in the digestive gland and is negatively regulated during fasting by the absence of food, whereas the intracellular lipase is expressed in various tissues 
(digestive gland, uropods, pleopods, digestive tube, gills, hemocytes, muscle and gonad), and is positively regulated during starvation, suggesting that it is responsible for lipid mobilization from lipid depots (energy reserves).

Based on these previous studies and our present results, we propose a possible regulation pathway for the digestive lipase activity, which is summarized in Fig. 4. We hypothesize that the detection of food promotes de novo synthesis of digestive lipase (ABF and NABF treatments). Subsequently, manipulation, ingestion, stomach food content and nutritive molecules in the digestive gland stimulate digestive lipase secretion into the digestive gland ducts and stomach, interacting with food and carrying out degradation in both sections of the digestive tract (ABF). Therefore, the digestive lipase present in the stomach, intestine and digestive gland is acting on the food and cannot be fully quantified when the lipase activity is measured solely in the digestive gland (Fig. 4A). This would agree with the fact that digestive lipase activity does not increase when food is available (ABF). Therefore, the presence of food inside the stomach, and subsequent products of stomach digestion in the digestive gland and intestine would stimulate further degradation of the food. However, detection of food inhibits the intracellular lipase synthesis pathway, and thus stored lipids are not used as an energy source.

When there is no food in the environment for a long period of time, the intracellular lipase de novo synthesis is likely to be stimulated, and as a consequence, lipid stores mobilized. The pathway of digestive lipase synthesis is inhibited and digestive lipase remains at basal levels (Fig. 4B). In the present study, this assumption is supported by our observation of the low level of digestive lipase activity recorded in the control group after $16 \mathrm{~d}$ of fasting. However, when food is present but not available (only possible under experimental conditions), digestive lipase is synthesized and stored inside digestive gland cells and is not secreted. This could be due to the fact that there is no handling stimuli, ingestion, food content in the stomach, and food stomach digestion products in the digestive gland. However, because the synthesis of intracellular lipase is likely to be inhibited in the short-term, there may or may not be a mechanism to counteract this experimental effect (Fig. 4C) i.e. when $C$. quadricarinatus detects the presence of food, the intracellular lipase synthesis is not active to restrict mobilization of lipid reserves and the synthesis of extracellular digestive lipase is also stimulated, in spite of the presence or absence of food in the stomach and digestive gland. This assumption is supported by our observation of increased activity of digestive lipase in the NABF treatment of this study.

Protease and trypsin activities reflected a similar response to food availability after $16 \mathrm{~d}$ of fasting. This result supports the concept that trypsin (together with chymotrypsin) is one of the main proteases of the digestive gland in decapod crustaceans, and it is believed to be responsible for 40 to $60 \%$ of total protein digestion in penaeids (Galgani et al. 1984, Tsai et al. 1986).

Our results show that the presence of available food stimulates trypsin secretion at $120 \mathrm{~min}$ after long-term starvation but not after short-term starvation. It is possible that during short fasts, the levels of digestive capacity do not decrease significantly because of the history of previous food. The result of the differential response of trypsin secretion under different fasting periods is related to the findings of Muhlia-Almazán \& García-Carreño (2002), who reported that trypsin activity from the hepatopancreas in $L$. vannamei was diminished in response to fasting. Cuzon et al. (1980) demonstrated that trypsin activity in shrimp decreases during starvation. In turn, C. quadricarinatus juveniles exposed to nonaccessible food after $16 \mathrm{~d}$ of fasting show an increase in trypsin activity relative to the $\mathrm{ABF}$ group, which would indicate that it might be stored inside digestive gland cells until food entry to the digestive system. This is also related to the results reported by Hernández-Cortés et al. (1999), who demonstrated the presence of trypsinogen in the digestive gland of the crayfish Pacifastacus leniusculus. Furthermore, Sainz et al. (2004), in their study on trypsin synthesis and storage as zymogen in fed and fasted individuals of $L$. vannamei, revealed that trypsinogen is not totally secreted from a single cell, but rather appears to be secreted partially as an effect of ingestion. It must be considered that trypsinogen can be spontaneously reactivated during the preparation of enzyme extracts and therefore be quantified as an active enzyme, such that it might not be distinguished from the enzyme that is activated and secreted for food digestion by natural causes (Sánchez-Paz et al. 2003). Therefore, more studies in C. quadricarinatus are needed to clarify this issue. More studies are also needed regarding possible changes in messenger expression, as well as immunohistochemical studies of digestive tract cells as a reflection of physiological changes in the digestive enzyme secretion in this species. We observed a differential response (in terms of reaction time) in lipase, protease and trypsin activity when food became available again after pro- 


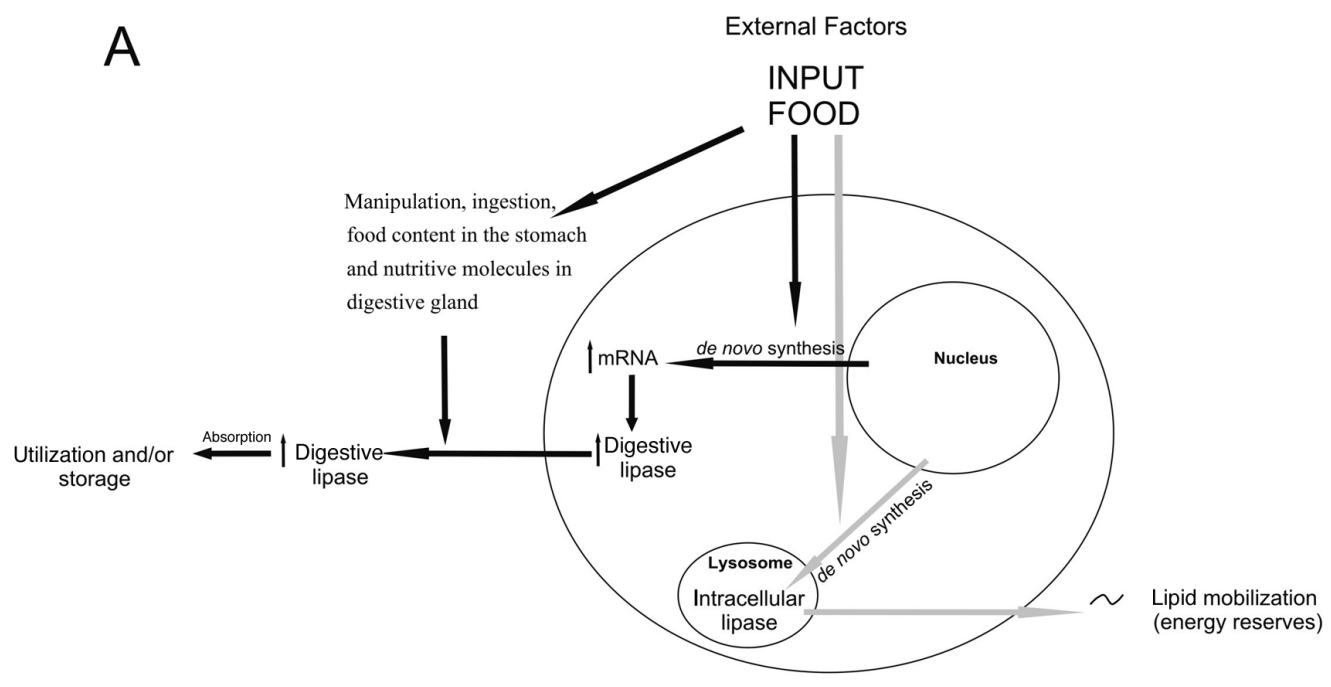

B

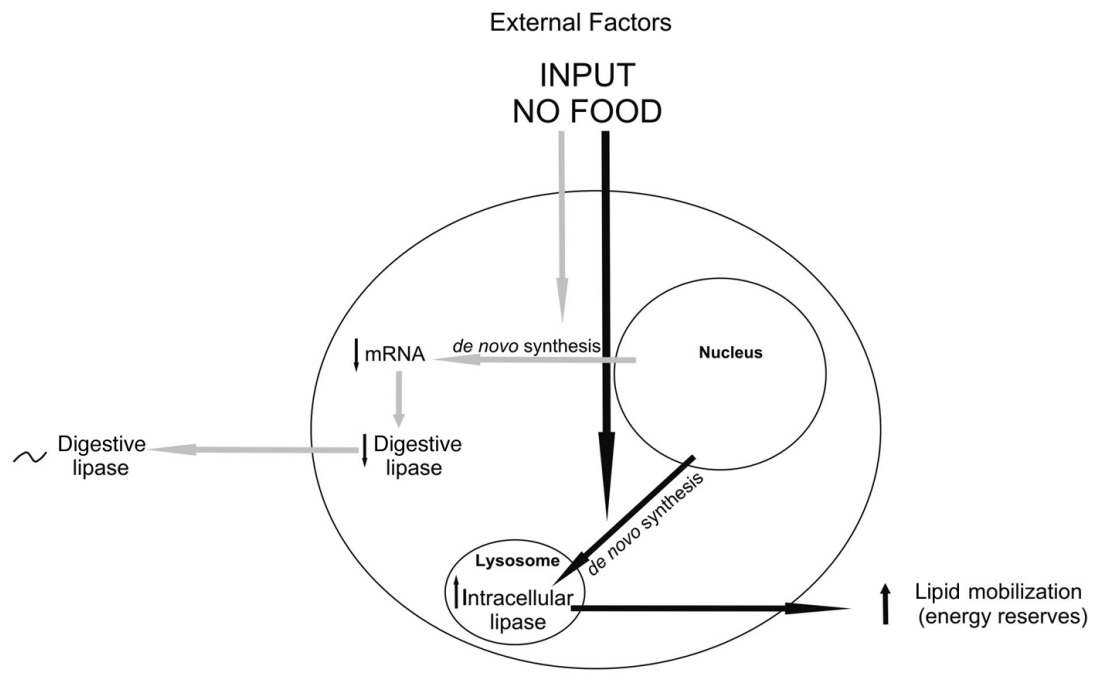

C

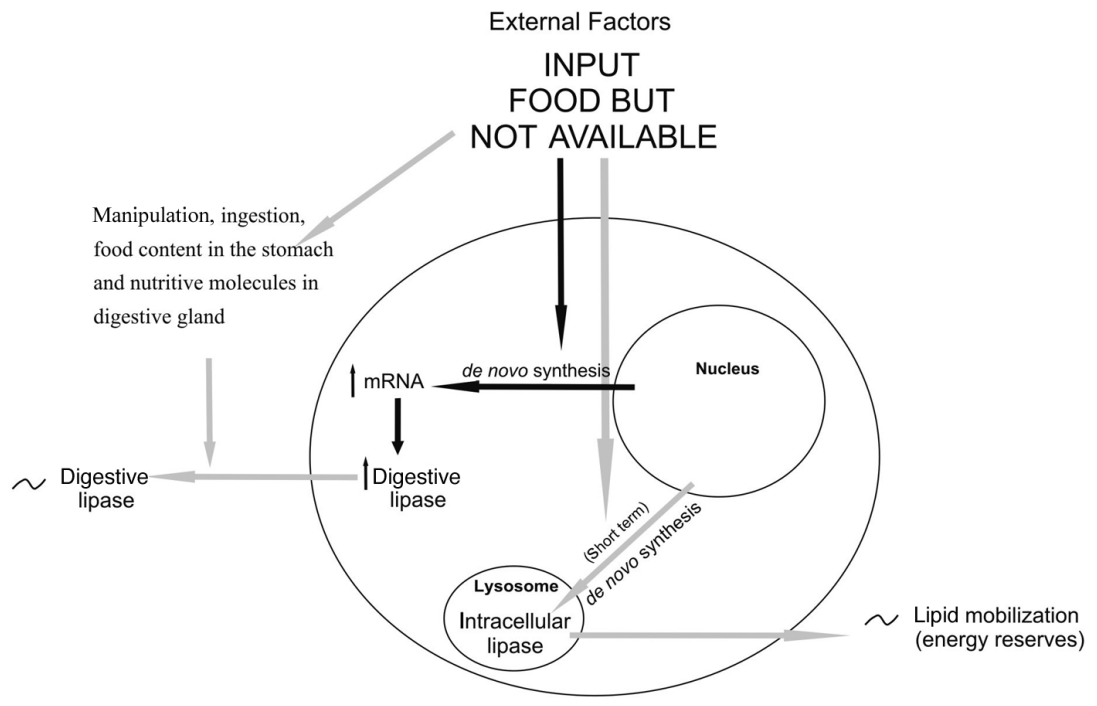

Fig. 4. Possible digestive and intracellular lipase regulation in the midgut gland of Cherax quadricarinatus according to Yudkovski et al. (2007), RiveraPérez \& García-Carreño (2011) Calvo et al. (2013) and the present study. (A) Feeding, (B) long-term starvation and (C) feed stimuli without ingestion. Black and grey arrows: stimulation and inhibitory pathways, respectively 
longed fasting $(16 \mathrm{~d})$. Lipase responded rapidly (after only $30 \mathrm{~min}$ ) to the presence of food, whereas protease and trypsin levels responded only after $120 \mathrm{~min}$. Therefore, these enzymes could be used as a tool to analyze the nutritional status of $C$. quadricarinatus.

During periods of starvation, crustaceans must use their energy reserves to meet their needs, and so enzymatic activity must be finely regulated to degrade the necessary energy reserves while preserving cell integrity as much as possible (Sánchez-Paz et al. 2006). Hence, changes in food intake during development may have important consequences for life history (Brzek \& Konarzewski 2001). Although instantaneous ecological consequences of poor and sporadic nutrition are sometimes difficult to identify, the reproductive potential of any organism experiencing such conditions may be reduced (SánchezPaz et al. 2006).

Acknowledgements. This study was part of H.J.S.'s postgraduate scholarships (ANPCYT and CONICET) and PhD dissertation (University of Buenos Aires, Argentina). We are grateful to Dr. Raymond Bauer, University of Louisiana, Lafayette, LA, USA, and to the reviewers for their comments to improve the manuscript, to Lic. Amir Dyzenchauz for language revision, to Centro Nacional de Desarrollo Acuícola (CENADAC, Argentina) for providing the reproductive stock and to Dr. Gerado Cueto for his help with the statistical analysis. L.S.L.G. is grateful to Agencia Nacional de Promoción Científica y Tecnológica (PICT 2007, project 01187 and 2012 project 01333), CONICET (PIP 2009-2011, number 129 and PIP 2012-2014), UBACYT (projects X458 and 20020100100003), MINCYT-CONACYT (México) MX/09/07 and MINCYT-CAPES BR/11/21 for funding this research.

\section{LITERATURE CITED}

Ameyaw-Akumfi CE, Hazlett BA (1975) Sex recognition in the crayfish Procambarus clarkii. Science 190:1225-1226 AOAC (Association of Official Analytical Chemists) (1990) Official methods of analysis of the Association of Official Analytical Chemists. AOAC, Arlington, VA

Arredondo-Figueroa JL, Ponce-Palafox JT, Shirai-Matsumoto K, Pérez-Zavaleta A, Barriga-Sosa I, Luna AR (2013) Effects of including shrimp protein hydrolysate in practical diets on the growth and survival of redclaw crayfish hatchlings Cherax quadricarinatus (von Martens, 1868). Aquacult Res 44:966-973

Barclay MC, Dall W, Smith DM (1983) Changes in lipid and protein during starvation and the moulting cycle in the tiger prawn, Penaeus esculentus (Haswell). J Exp Mar Biol Ecol 68:229-244

Boyd CE, Tucker CS (1998) Pond aquaculture water quality management. Kluwer Academic Publishers Group, Norwell, MA

Bradford MM (1976) A rapid and sensitive method for the quantitation of microgram quantities of protein utilizing the principle of protein-dye binding. Anal Biochem 72: 248-254
Brzek P, Konarzewski M (2001) Effect of food shortage on the physiology and competitive abilities of sand martin (Riparia riparia) nestlings. J Exp Biol 204:3065-3074

Bugnot A, López Greco LS (2009) Sperm production in the freshwater crayfish Cherax quadricarinatus (Decapoda, Parastacidae). Aquaculture 295:292-299

Calvo N, Stumpf L, Sacristán HJ, López Greco LS (2013) Energetic reserves and digestive enzyme activities in juveniles of the red claw crayfish Cherax quadricarinatus nearby the point-of-no-return. Aquaculture 416-417: 85-91

Clifford HC, Brick RW (1983) Nutritional physiology of the freshwater shrimp Macrobrachium rosenbergii (De Man): I. Substrate metabolism in fasting juvenile shrimp. Comp Biochem Physiol A 74:561-568

Comoglio L, Goldsmit J, Amin O (2008) Starvation effects on physiological parameters and biochemical composition of the hepatopancreas of the southern king crab Lithodes santolla (Molina, 1782). Rev Biol Mar Oceanogr 43:345-353

Cuzon G, Cahu C, Aldrin JF, Messager JL, Stephan G, Mevel M (1980) Starvation effect on metabolism of Penaeus japonicus. Proc World Maric Soc 11:410-423

Díaz AC, Fernández Gimenez AV, Fenucci JL (1999) Evaluación del extracto proteico de calamar en la nutrición del langostino argentino Pleoticus muelleri Bate (Decapoda, Penaeoidea). Acuicultura en Armonía con el Ambiente, Acuicultura Venezuela 1999, 1:84-192

Dunham DW, Oh JW (1992) Chemical sex discrimination in the crayfish, Procambarus clarkii: role of antennules. J Chem Ecol 18:2363-2372

Erlanger BF, Kokowsky N, Cohen W (1961) The preparation and properties of two new chromogenic substrates of trypsin. Arch Biochem Biophys 95:271-278

> Fenucci JL, Zein-Eldin ZP, Lawrence AL (1980) The nutritional response of two penaeid species to various levels of squid meal in a prepared feed. Proc World Maricul Soc 11:403-409

Fernández Gimenez AV, Díaz AC, Velurtas SM, Fenucci JL (2009) Partial substitution of fishmeal by meat and bone meal, soybean meal, and squid concentrate in feeds for the prawn, Artemesia longinaris: effect on digestive proteinases. Isr J Aquacult Bamidgeh 61:48-56

Galgani ML, Benyamin Y, Ceccaldi HJ (1984) Idecation of digestive proteinases of Penaeus kerathurus (Forskal): a comparison with Penaeus japonicus Bate. Comp Biochem Physiol Part B 78:355-361

García-Carreño FL (1992) The digestive proteases of langostilla (Pleuroncodes planipes, Deapoda): their partial characterization, and the effect of feed on their composition. Comp Biochem Physiol B 103:575-578

Gillespie J (1990) Redclaw: a hot new prospect. Aust Fish 49: 2-3

Gu H, Mather PB, Capra MF (1994) The relative growth of chelipeds and abdomen and muscle production in male and female redclaw crayfish, Cherax quadricarinatus von Martens. Aquaculture 123:249-257

Gutiérrez ML, Rodríguez EM (2010) Effect of protein source on growth of early juvenile redclaw crayfish Cherax quadricarinatus (Decapoda, Parastacidae). Freshw Crayfish 17:23-29

Harpaz S, Kahan D, Galun R, Moore I (1987) Responses of freshwater prawn, Macrobranchium rosenbergii, to chemical attractants. J Chem Ecol 13:1957-1965

> Hazlett BA (1989) Additional sources of disturbance phero- 
mone affecting the crayfish Orconectes virilis. J Chem Ecol 15:381-385

- Heinen JM (1980) Chemoreception in decapod Crustacea and chemical feeding stimulants as potential feed additives. Proc World Maric Soc 11:317-334

Hernández-Cortés P, Cerenius L, García-Carreño FL, Soderhall K (1999) Trypsin from Pacifastacus leniusculus hepatopancreas: purification and cDNA cloning of the synthesized zymogen. Biol Chem 380:499-501

Icely JD, Nott JA (1992) Digestion and absorption: digestive system and associated organs. In: Harrison FW, Humes AG (eds) Microscopic anatomy of invertebrates, Vol 10: decapod Crustacea. Wiley-Liss, New York, NY, p 147-201

Jaime-Ceballos B, Civera Cerecedo R, Villarreal H, Galindo López J, Pérez-Jar L (2007) Use of Spirulina platensis meal as feed attractant in diets for shrimp Litopenaeus schmitti. Hidrobiológica 17:113-117

> Jones CM (1995) Production of juvenile redclaw crayfish, Cherax quadricarinatus (von Martens) (Decapoda, Parastacidae) II. Juvenile nutrition and habitat. Aquaculture 138:239-245

Jones CM (1997) The biology and aquaculture potential of the tropical freshwater crayfish, Cherax quadricarinatus. Department of Primary Industries, Report No. QI90028, Brisbane

> Jones PL, Obst JH (2000) Effects of starvation and subsequent refeeding on the size and nutrient content of the hepatopancreas of Cherax destructor (Decapoda: Parastacidae). J Crustac Biol 20:431-441

Karavanich C, Atema J (1998) Individual recognition and memory in lobster dominance. Anim Behav 56:1553-1560

> Kozlowski O, Voigt R, Moore P (2003) Changes in odour intermittency influence the success and search behaviour during orientation in the crayfish (Orconectes rusticus). Mar Freshw Behav Physiol 36:97-110

Kreider JL, Watts SA (1998) Behavioral (feeding) responses of the crayfish, Procambarus clarkii, to natural dietary items and common components of formulated crustacean feeds. J Chem Ecol 24:91-111

> Kurmaly K, Jones DA, Yule AB (1990) Acceptability and digestion of diets fed to larval stages of Homarus gammarus and the rule of dietary conditioning behavior. Mar Biol 106:181-190

> Lee PG, Meyers SP (1996) Chemoattraction and feeding stimulation in crustaceans. Aquacult Nutr 2:157-164

> Levi T, Barki A, Hulata G, Karplus I (1999) Mother-offspring relationships in the redclaw crayfish Cherax quadricarinatus. J Crustac Biol 19:477-484

López-López S, Nolasco H, Villarreal-Colmenares H, Civera Cerecedo R (2005) Digestive enzyme response to supplemental ingredients in practical diets for juvenile freshwater crayfish Cherax quadricarinatus. Aquacult Nutr 11:79-85

> Loya-Javellana GL, Fielder DR, Thorne MJ (1995) Foregut evacuation, return of appetite and gastric fluid secretion in the tropical freshwater crayfish, Cherax quadricarinatus. Aquaculture 134:295-306

Mackie AM (1973) The chemical basis of food detection in the lobster Homarus gammarus. Mar Biol 21:103-108

Mackie AM, Shelton RG (1972) A whole animal bioassay for the determination of the food attractants of the lobster Homarus gammarus. Mar Biol 14:217-221

- Mendoza R, Montemayor J, Verde J (1997) Biogenic amines and pheromones as feed attractants for the freshwater prawn Macrobrachium rosenbergii. Aquacult Nutr 3: 167-173

Merrick JR, Lambert CN (1991) The yabby, marron and red claw: production and marketing. Macarthur Press, Parramatta

Moore PA, Grills JL (1999) Chemical orientation to food by the crayfish Orconectes rusticus: influence of hydrodynamics. Anim Behav 58:953-963

> Muhlia-Almazán A, García-Carreño FL (2002) Influence of molting and starvation on the synthesis of proteolytic enzymes in the midgut gland of the white shrimp Penaeus vannamei. Comp Biochem Physiol B 133:383-394

> Nunes AJP, Sá MVC, Andriola-Neto FF, Lemos D (2006) Behavioral response to selected feed attractants and stimulants in Pacific white shrimp, Litopenaeus vannamei. Aquaculture 260:244-254

> Ong BL, Johnston D (2006) Influence of feeding on hepatopancreas structure and digestive enzyme activities in Penaeus monodon. J Shellfish Res 25:113-121

> Rivera-Pérez C, García-Carreño F (2011) Effect of fasting on digestive gland lipase transcripts expression in Penaeus vannamei. Mar Genomics 4:273-278

Sacristán HJ, Franco Tadic LM, López Greco LS (2013) Influencia de la alimentación sobre el ritmo circadiano de las enzimas digestivas en juveniles de engorde de la langosta de agua dulce Cherax quadricarinatus (Parastacidae). Lat Am J Aquat Res, 41:753-761

Sainz JC, García-Carreño F, Sierra-Beltrán S, HernándezCortés P (2004) Trypsin synthesis and storage as zymogen in the midgut gland of the shrimp Litopenaeus vannamei. J Crustac Biol 24:266-273

Sánchez de Bock M, López Greco LS (2010) Sex reversal and growth performance in juvenile females of the freshwater crayfish Cherax quadricarinatus (Parastacidae): effect of increasing temperature and androgenic gland extract in the diet. Aquacult Int 18:231-243

Sánchez-Paz A, García-Carreño F, Mulhia-Almazán A, Hernández-Saavedra N, Yepiz-Plascencia G (2003) Differential expression of trypsin mRNA in the white shrimp (Penaeus vannamei) midgut gland under starvation conditions. J Exp Mar Biol Ecol 292:1-17

Sánchez-Paz A, García-Carreño F, Muhlia-Almazán A, Peregrino-Uriarte AB, Hernández-López J, Yepiz-Plascencia G (2006) Usage of energy reserves in crustaceans during starvation: status and future directions. Insect Biochem Mol Biol 36:241-249

Saoud IP, Ghanawi J (2013) A review of the culture and diseases of redclaw crayfish Cherax quadricarinatus (von Martens 1868). J World Aquacult Soc 44:1-29

Saoud IP, Garza De Yta A, Ghanawi J (2012) A review of nutritional biology and dietary requirements of redclaw crayfish Cherax quadricarinatus (von Martens 1868). Aquacult Nutr 18:349-368

Saoud IP, Ghanaw IJ, Thompson KR, Webster CD (2013) A review of the culture and diseases of redclaw crayfish Cherax quadricarinatus (von Martens 1868). J World Aquacult Soc 44:1-29

> Smith DM, Tabrett SJ, Barclay MC, Irvin SJ (2005) The efficacy of ingredients included in shrimp feeds to stimulate intake. Aquacult Nutr 11:263-271

Sokal RR, Rohlf FJ (1995) Biometry: the principles and practice of statistics in biological research, 3rd edn. WH Freeman, New York, NY

Stumpf L, Calvo NS, Pietrokovsky S, López Greco LS (2010) Nutritional vulnerability and compensatory growth in 
early juveniles of the 'redclaw' crayfish Cherax quadricarinatus. Aquaculture 304:34-41

Tamburri MN, Finelli CM, Wethey DS, Zimmer-Faust RK (1996) Chemical induction of larval settlement behaviour in flow. Biol Bull 191:367-373

Tierney AJ, Atema J (1988) Behavioral responses of crayfish (Orconectes virilis and Orconectes rusticus) to chemical feeding stimulants. J Chem Ecol 14:123-133

Tierney AJ, Dunham DW (1982) Chemical communication in the reproductive isolation of the crayfishes Orconectes propinquus and Orconectes virilis (Decapoda, Cambaridae). J Crustac Biol 2:544-548

Tropea C, Piazza Y, López Greco LS (2010) Effect of longterm exposure to high temperature on survival, growth and reproductive parameters of the 'redclaw' crayfish Cherax quadricarinatus. Aquaculture 302:49-56

Tsai IH, Chuang KL, Chuang JL (1986) Chymotrypsin in digestive tract of crustacean decapods (Shrimps). Comp Biochem Physiol Part B 85:235-239

> van Wormhoudt A (1974) Variations of the level of the digestive enzymes during the intermolt cycle of Palaemon sereratus: influence of the season and effect of the eyestalk ablation. Comp Biochem Physiol A 49:707-715

Vazquez FJ, Tropea C, López Greco LS (2008) Development of the female reproductive system in the freshwater crayfish Cherax quadricarinatus (Decapoda, Parastacidae). Invertebr Biol 127:433-443

> Vega-Villasante F, Nolasco-Soria H, Civera R (1993) The digestive enzymes of the Pacific brown shrimp Penaeus

Editorial responsibility: Bernard Sainte-Marie, Mont-Joli, Quebec, Canada californiensis.: I-Properties of amylase activity in the digestive tract. Comp Biochem Physiol B 106:547-550

Vega-Villasante F, Fernández I, Oliva M, Preciado $M$, Nolasco-Soria H (1999) The activity of digestive enzymes during the molting stages of the arched swimming Callinectes arcuatus Ordway, 1863 (Crustacea: Decapoda: Portunidae). Bull Mar Sci 65:1-9

- Versaw KW, Cupper LS, Winters DD, Williams EL (1989) An improved colorimetric assay for bacterial lipase in nonfat dry milk. J Food Sci 54:1557-1568

Weissburg M (2011) Waterborne chemical communication: stimulus dispersal dynamics and orientation strategies in crustaceans. In: Breithaupt $\mathrm{T}$, Thiel $\mathrm{M}$ (eds) Chemical communication in crustaceans. Springer-Verlag, New York, NY, p 63-83

Yudkovski Y, Shechter A, Chalifa-Caspi V, Auslander M and others (2007) Hepatopancreatic multitranscript expression patterns in the crayfish Cherax quadricarinatus during the moult cycle. Insect Mol Biol 16:661-674

Zar JH (1999) Biostatistical analysis, 4th edn. Prentice-Hall, Upper Saddle River, NJ

Zulandt Schneider RA, Schneider RWS, Moore PA (1999) Recognition of dominance status by chemoreception in the crayfish, Procambarus clarkii. J Chem Ecol 25:781-794

Zuur AF, Ieno EN, Walker NJ, Saveliev AA, Smith GM (2009) Mixed effects models and extensions in ecology with R. In: Gail M, Krickeberg K, Samet JM, Tsiatis A, Wong W (eds) Statistics for biology and health. SpringerVerlag, New York, NY, p 323-339

Submitted: April 30, 2014; Accepted: October 22, 2014 Proofs received from author(s): December 4, 2014 